\title{
Workers' Behaviour and Interests in Socialist Society
}

\author{
Csaba Makó
}

\section{The Common Theoretical Source of Deterministic and Voluntaristic Approaches: Conceptions of the Mechanical Unity of Interests}

In the decade following the liberation of Hungary in 1945, the image of workers' actions was imbued with the idea that the primary and final aim of working-class resistance within capitalism is the overthrow of the capitalist social system. With the elimination of capitalist ownership, there is no longer any basis for workers' resistance to representatives of the company or the state. The elimination of private ownership of the means of production liberates social relations from the all-pervasive and irreconcilable antagonism between capital and labour.

A significant role in this simplified analysis of workers' behaviour is played by the well-known concept of the working class as either a 'class in itself' or a 'class for itself'. In essence, the 'working class in itself' is brought into existence by the objective economic relations of capitalism, whereas the 'working class for itself' is the subjectively mature working class which consciously recognizes its own position, is aware of its own historical mission, and is prepared to undertake collective actions and effect the overthrow of capitalist society. In this approach, the 'non-conscious', subjectively immature working class is necessarily transformed into a class 'for itself', whose members are the class-conscious workers. The transformation is only a question of time, as the maturation of the objective economic conditions inevitably intensifies the conflict between capital and labour. The working class comes to realize its subordinate position, and recognizes that this subordination can be changed only through organized collective struggle.

A concomitant to this theory is the idea that the development of working-class consciousness can be substantially accelerated by political organizations representing the workers' interests: a class-conscious working class will result from the activity of the political parties and trade unions of the working class. ${ }^{1}$

The dichotomous categories illustrating working-class action, however, have only limited application for changes within the capitalist mode of production. For example, they are not useful for understanding the success of economic and political reforms in maintaining the continuity, and staving off the collapse, of a given capitalist society. Many of Marx's adherents have followed Marx in neglecting the analysis of interest and power conflicts on the local and individual levels. Thus, discussion of those conflicts that are 'under normal circumstances manifestations of 
class struggle' is particularly abstract - from the peculiarities not only of local class struggles but also of different capitalist countries. ${ }^{2}$

Parallel to the emergence of socialist property relations in Hungary there appeared views of politics and economic management that deduced workers' orientations towards work and towards the enterprise directly from certain definite 'objective conditions'. These views emphasized almost exclusively the undeniably enormous changes that had taken place in property relations. However, they took no account of the work processes of the nationalized factories, of their organizational relations, or of the forms and content of the evolving social connections. In the simplified, romantic image of socialist development, they overlooked the fact that the overthrow of capitalist property relations did not include the overthrow of the relations of division and specialization of labour. ${ }^{3}$ Furthermore:

If the [fragmented and hierarchical] character of the work does not make it possible for workers to survey the production process then their control of property cannot prevail completely. Although by activity outside the work process some forms of indirect rule can be achieved, such a relation to property is still not the same as that of the persons governing the production process. ${ }^{4}$

These analyses also forgot that workers' behaviour within production is influenced by social connections and the alternatives of action outside the work process. They paid minimal attention, for example, to the formation of relations between the character of production practices and the 'reproductional conditions' of the manpower participating in it, and to the effects produced by these conditions on work-place behaviour.

In the analytical scheme outlined above, the individual or collective conduct of workers can be understood only on the basis of the common interests characteristic of the entire working class, which develop almost automatically with the overthrow of capitalist property relations.

On the level of macro-structural analysis, the principal particularity of the period was that the political sphere failed to acknowledge the relative autonomy of the processes taking place in the economy. Therefore it determined that social mechanisms mediating between the political and the economic system were unnecessary. But according to this view, behaviour in the work process was guided not by the development of particular interests and the ability to realize them, but by political will, 'knowing all, seeing all and being omnipotent'.'

Thus, the unity of action necessary to realize production aims can be simply deduced from property relations freed from exploitation, and from the resultant (supposed) collective interest. Conflicts of interest are not to be found in this conception, which denies the existence both of differences of interests and of inequality in the possibility of acting on those interests. There is recognition of such differences only in terms of the role played by individual consciousness in the perception of social and economic conditions. Such outward forms of workers' behaviour as, for example, 
the level of work performance have been explained in this way. Those who perform the best are those workers possessing the most developed consciousness, that is those who see their own interests, based on socialist property relations, as identical to the interests of society as a whole. Weak work performance comes from 'backward' workers, of 'undeveloped consciousness', among whom there is inadequate motivation.

In the thinking and practice of the decade following the liberation of 1945 , the views interpreting workers' behaviour are inseparable from the conception declaring the mechanical unity of interests in society. The thesis of the mechanical unity of interests can be summarized as follows. As a consequence of the replacement of capitalist property relations by socialist (state-owned) property relations, the conflictual class relations of capitalist society, based on the contradiction between socialized forces of production and private appropriation of surplus, come to an end and the unity of interests and, consequently, of action come into being. On the basis of this view, the policy-making process of the period directly following liberation dealt with the mentality of the workers in connection with production and distribution with increased expectation and confidence. Mátyás Rákosi, for instance, appreciated the inarguably great work performance during reconstruction:

Most of the factories remained without a director after the liberation and often without leading engineers. It was the workers who restored these factories and put them into operation. Meanwhile they made great sacrifices, sacrifices which will doubtless constitute the most brilliant pages of the Hungarian workers' movement. They did not see a director for weeks or even months and this led them to believe that they could run the factories without capitalists too. The young Hungarian democracy assured far-reaching rights ... to the workers ... in the direction of the plant. ${ }^{6}$

In this quotation the deterministic behaviour is based on the notion of a self-conscious working class, a class 'for itself'; it is presumed that after the elimination of capitalist ownership of the means of production the relation of workers to the factory and to work itself is radically transformed within weeks or months. Such an image of workers is not confined to Hungary. In the world of work - as well as in other activity areas of society - images of social harmony and conflict-free societies dominate the foreign practice of building socialism as well. Plenty of examples are to be found in Soviet novels dealing with production. The plot of many of these unfolds in the 'conflict-free' world of some enterprise, roughly according to the following scheme:

In the novel everything is reflected: the activity of the engineers and technicians as well as that of the factory organizations, the workers on top, their wives and fiancées, the learning, the culture group, the traditional old non-party man, who has already been working in this factory for fifty years and offers a miraculously wise opinion about all 
phenomena of life. Somebody discovers something, somebody is mistaken in something (not for long), somebody is in love with somebody (not too ardently). They describe two meetings in which the entire collective participates; the red table cloth is mentioned along with the carafe on the table of the chairman. The factory worries about the fulfilment of the plan; the author explains to his readers what is undermining the fulfilment of the difficult plan; by the end of the novel through the help of the heroes the difficulties will have been overcome, the plan will have been fulfilled early, the workers on top are rewarded, the anti-hero will be detected by the collective.

However, it soon emerges that in the world of work, just as in other fields of society, there exist forms of behaviour inconsistent with the officially declared interest of the whole society. But, since objective interest contradictions may not exist in socialist society or socialist enterprises, workers' behaviour differing from the societal or enterprise aims is explainable only by the presence of the 'enemy' or by 'backward consciousness' - that is, by factors external to the functioning of the social system.

According to the interpretations emphasizing the role of consciousness, the thinking of one group of workers falls behind the development of socialist social conditions: these workers are unable to comprehend, for example, what is correct as regards performance and wages. A significant fraction of these workers are 'loafers' and those who restrict their output. These 'backward' workers undermine the efforts of the conscious, disciplined workers, who

... fiercely and spontaneously take measures against the undisciplined ones. They do this not only because they also suffer as the consequence of the lack of discipline, but because they comprehend that the relaxation of labour discipline hinders the entire project of socialist construction, the development of the country. The conscious workers also learn that such undisciplined workers, as a means of self-justification, are always dissatisfied, grumbling, blustering, and finding fault, and thus become the spokesmen of the enemy. ${ }^{8}$

These oppositional and socially undesirable forms of behaviour, often manifesting themselves in connection with performance requirements, occur primarily among workers of low consciousness. Behind the apparent moralizing condemnation of work-place behaviour, a changed conception of the role of the working class can be discovered. No longer is there reference to the working class 'for itself', but more and more a conception of the working class 'in itself' can be identified in the interpretation of workers' behaviour. Furthermore, such a conception provides a sort of political programme based on the view that one part of the working class is still subjectively immature and therefore unaware of 
its historic mission. Accordingly, wide educational work should be done in order to make these workers 'conscious'.

The other source of undesirable behaviour is to be found in the hostile environment outside the socialist system. The lack of work discipline, the poor quality of work or the systematic restriction of output is attributed to the disruptive activity of imperialist agents. Ernö Gero ascribed the inflation of workers' wages in the 1950 s to the action of the enemy:

... in the increase of wages to such an extent no small part was played by the fact that while we were busy with other questions, the enemy could exploit this situation and took advantage of the fact that in many of the workers both the consciousness and the discipline were yet weak; the enemy succeeded in opening a new front against the democracy; namely the front of the mass manipulation of wages and norms. ${ }^{9}$

These simple and distorted pictures of the response to work norms are part of that social policy that did not want to deal with the actual motivation and possibilities of work-place behaviour but considered it sufficient to handle the problems in a moralizing and administrative way. Failure to examine this view excessively exaggerated and thereby made a fetish of the influence of capitalism, while questioning the autonomous social force and dynamism of labour. Without doubt, the sharp ideological struggle between the two types of social system was partly responsible. During the cold war, especially, the ideologists of capitalist industrial relations tended to attribute their internal troubles to external communist agitation. Thus, American journalists attributed strikes to the activity of communist-minded trade union stewards. The exclusion of other explanations for strikes had an unmistakable political and ideological purpose: it created an opportunity for campaigns against progressive and active trade union shop stewards and for the generation of anti-communist hysteria. ${ }^{10}$ The communist members of the American trade union movement protested against these interpretations, but their intervention remained ineffective.

The responses to workers' action were not exhausted by moralizing explanations. A wide arsenal of means was applied to incite desired forms of behaviour and to punish undesired ones. At the level of the enterprise, management strove to establish harmony between individual goals and those of the whole nation by means of pecuniary incentives and various forms of consciousness-raising.

If 'problematic behaviour' - for example, restriction of output or frequent absence from work - is explained as the product of the underdevelopment of consciousness relative to our social relations, then we have to select corresponding methods of getting over the lag. Thus, piecerates became the decisive form of socialist wage in these years.

In the years immediately following liberation, scarcely more than onethird of the workers engaged in industry were paid by piece-rates. ${ }^{11}$ National and foreign investigations into the relation of work performance 
to wages do not warrant expectations of heightened efficiency as a result of the piece-rate system. The fact-finding investigation of the International Labour Organization, already several decades old, concluded that:

The positive effect of the piece-rate system waging or in general of the pecuniary incentives on work performance succeeds through the modernization of the methods of work performance. At the same time, one can also achieve results of such a character of the work organization independently of alterations in the wage system. ${ }^{12}$

National as well as foreign experiences repeatedly call attention to the negative social and economic effects of the piece-rate system. ${ }^{13}$ In spite of this, the piece-rate system has invariably kept its leading position among wage forms. According to the statistical assessment of employees in stateowned industry, for example, even today more than half of those working on machines and more than 90 per cent of workers employed on assembly lines labour under piece-rate systems. ${ }^{14}$

In addition to pecuniary incentives the authorities applied a wide range of consciousness-raising techniques. Their aim was, as noted above, to raise the consciousness of the workers of work collectives to the level at which their own ambitions become one with the interests of society. Not only professional propagandists but agit-propagandists chosen from higher levels of workers also dealt with the formation of consciousness.

An account of the role of the agitator-worker, and his methods of consciousness-raising, is given as follows:

It is a very common phenomenon for our agitators generally to make a comparison between the former life of the workers, the life of the workers in the capitalist countries and our present situation. In the Kispest Textile Factory (Kistext) woman comrade Mrs Jozsef Nemeth, a Stakhanovite agit-propagandist, talked with Miss Erzsebet Vali on the fulfilment of the plan. In the course of the talk she said, approximately, 'What you have pledged is that you have to perform since the plan is the law. By this you defend your fatherland, the people's democracy and peace. Our economic situation is steadily improving. You can see that even rationing has come to an end. All this is the latest success of our party, government and working people. You can also see that the meat ration is 80 grammes a week in England, the transport fares have been raised by 25 per cent, while we steadily grow firm and develop. ${ }^{15}$

The political leadership of this period applied strong measures when they thought that undesirable work-place behaviour was the work of 'outside' enemies. When restriction of output, 'manipulation of the norms', increases in the percentage of waste or degeneration of work discipline was diagnosed as the result of instigation by an imperialist agent, the instigator was arrested or interned or, in less serious cases, dismissed. ${ }^{16}$

Neither by the different systems of piece-rates nor by ideological and 
administrative measures did social policy makers succeed in persuading significant numbers of workers to accept the "interests of the whole society', which were interpreted within the enterprise as working conditions resulting in maximum performance. It turned out that under socialism, as in every complex and rapidly changing society, the realization of aims and strivings expressing a requirement of development is possible only through the recognition and coordination of the interests of all social strata, groups and individuals taking part in that realization.

However, the harmonization of interests is a process charged with social and psychological conflicts. For example, the compromise of interests around the question of work performance and distribution affects the individual or collective interests of participants unevenly in time and space. In the work process mutual understanding emerges or disappears not at all automatically but rather through a succession of conflicts. Interest structures condition workers' behaviour and the outcome of conflicts; compared with this the relative backwardness of the individual or collective consciousness is of secondary significance.

\section{Social Policy-Making for Differentiated Interests: A Multidimensional Conception of Interests}

It was asserted above that the structural and hierarchical relations of the social division of labour cannot be 'overthrown' through revolution, and that therefore the diversity of interests and action possibilities must be taken into consideration. The system of political and economic policy can only moderate and limit the intensity and effect of the interest differences characteristic of certain periods of social development and the social capacities and opportunities affecting their realization. The incentive methods applied to influence the individual or collective behaviour of workers become factors of development only if they take into consideration actual interest and action relations.

Since the early 1960 s, the concept of differentiated interests has played a key role in the cognition and influence within national social policy of the real and structural roots of workers' behaviour. Furthermore, from the beginning of the 1970 s the image of a living, changing socialism deriving its evolutionary dynamism from interest conflicts, interwoven with objective interest relations, also appears in party documents. ${ }^{17}$ The most general characteristics of socialism "do not differ from capitalism in that there are no interest conflicts [in socialism] but do differ in that the class basis of the structural conflicts has come to an end'. ${ }^{18}$

The differentiation of processes in work organization can be explained on the one hand by the social division of labour within the enterprise, and on the other hand by the continuous changes taking place in the various components of the work process. Thus, it is easy to see that the objective social and economic factors defining the fundamental motives of workers' actions are inseparable from subjective factors - consciousness - and together they establish a multitude of systems of motives and incentives. 
The identification of different interests attempted to make this multitude manageable.

In the politics and social policy-making of the late 1960 s the threedimensional conception of interest make its appearance.

According to this we can speak of three types and levels of interests: those of the whole society, of groups and of individuals. The different types form a hierarchical system of relations. In the course of conflicts of interest, individual interests are subordinated to group interests, as the latter are to the interests of the whole society. If there arise tensions among the different types of interests, the higher interests always take precedence over the lower ones. ${ }^{19}$ The priority of the higher interests is guaranteed by the various organizations involved, by the institutions of social policy and by social movements. The threefold notion of interest or, as it is often called, the interest triad - was a significant development over the previous conception postulating and accepting only a single interest. The recognition of the existence of particular interests can also be considered an important conceptual part of the basis of the new economic reforms.

Sociological research of the 1970 s called attention to the weak or at least disputable points of the conception of the interest triad. The general experience of sociological investigations dealing with worker behaviour is that the structure of work-place interests is manifold and differentiated so that the 'interest of the whole society: group interest: individual interest' dimensions capture only a fraction of the real conflict of interest.

An understanding of our social and economic development requires the elaboration of a multidimensional notion of interests suitable for the description and comprehension of contradictory interests among different groups of workers at local as well as regional level. Such an elaboration does not serve immediate demands alone, as conflicting interests cannot be eliminated in the long run either. The tensions among the interests of the whole society as well as among partial interests, differing in form and intensity, remain long-lasting. Mutual agreements for easing them can be only temporary. ${ }^{21}$

Investigations into such well-known forms of work-place behaviour as performance, discipline, or the development of workers' participation have drawn attention to other important components of human behaviour besides relations among interests. The realization of individual and collective interests can be promoted or hindered by social attachments evolving at the work-place. The role of friendship in the satisfaction of individual interests is well reflected in the following remarks:

Here everyone is a friend and relies on it. So do I! Because if I need something I go to my mate, as no one does favours for anyone but his mates. And when my mate comes to me he gets priority over anyone else, even if what someone else wants is more important or more urgent [for the plant]. I have to think of who I'll go to next. ${ }^{22}$

According to Hungarian and foreign research into workers' behaviour, 
it is not possible to predict actual behaviour even through the most differentiated understanding of motives, taking into consideration behaviour motives as well as interests. This is because organizational relations do not ensure uniform conditions for the realization of perceived interests.

In the centre of human action - namely, in the work process - the possibilities for the acquisition of knowledge and the development of interests proceed very unevenly. The disproportion between the acquisition and the use of knowledge - general professional or specific to the work process - necessary for participation in any productive activity is the source of the differentiation of the capacity to realize interests. On the basis of analysis of interest relations themselves we may say only a little about the likelihood of the realization of interests. The 'price' of the compromise between interests can be determined and influenced only through knowledge of the capacities of the participants.

Without this one cannot predict the chances of the formation of an interest group. In conflicts arising among workers and management it is by no means easy to mobilize a collective force for the immediate realization of interests. Only in special - one might say historical - situations do those facing identical deprivations resolve their problems through common action. Collective action directed towards the elimination of deprivation, evaluated in an identical manner by different participants, is the result of a combination of numerous structural factors. Even supposing the automatic organization of interest groups, it is by no means inevitable that the participants in the work process, for example managers and staff, will recognize those forms of action through which their interests could most effectively be realized. Such a 'supra-rational' conception of organizational behaviour bears a close relationship to the pluralist notion of power as lying in the continuous presence and automatic development of interest groups - namely, the so-called 'pressure group'. ${ }^{23}$ However, research into the practice of industrial relations has not found an automatic development of interest groups. ${ }^{24}$

The different combinations of the material elements of the work process - the object of work and the instruments of work - offer various action possibilities for the subjective performer. In consequence of the disparities in their action possibilities, workers possess diverse opportunities, both as individuals and as collectives, to discover techniques of work performance and their usefulness for the realization of interests. In their work performance, it is not only the professionaltechnical knowledge of the workers that increases: simultaneously, the workers aquire a knowledge of the materials and tools and the operation of the machines. They 'learn' how to earn the most with the least effort that is, they 'learn' the amount of the desired and attainable wage. In this learning process, the worker gets to know not only himself but his companions as well. Depending on the peculiarities of the construction and operation of the work organization, he acquires a 'social knowledge' of diversified content and level far beyond the professional-technical 
knowledge. The disparities of the social experience mastered in this way lead to significant differences in the capacity to realize worker interests.

\section{NOTES}

Csaba Makó is Director of the Institute of Sociology of the Hungarian Academy of Sciences.

1. This conception of behaviour also influences Hungarian social scientific and political thought. This is confirmed by the discussions of the working class that were organized by the editorial committee of the Tarsadalmi Szemle (Social Review) in the early 1970s. On this see Mód Aladárné, 'Our Age and the Working Class', Társadalmi Szemle, 1970, No.6; Blaskovits János, 'On the Conception of the Working Class', Társadalmi Szemle, 1970, Nos.8-9; Halasi László, 'Meditation on Productive and Non-Productive Work', Társadalmi Szemle, 1970, Nos.8-9; Illes János, 'Some Problems on the Inner Stratification of the Hungarian Working Class', Társadalmi Szemle, 1970, No.11; Kovacs Ferenc, ' $\ldots$ Is this that Working Class?' Társadalmi Szemle, 1971, No.2; Mód Aladáme, 'Once Again: The Working Class Today', Társadalmi Szemle, 1971, No.4; Editorial Staff, 'To the Margin of the Working Class Discussion', Társadalmi Szemle, 1971, No.6.

2. P. Anderson, Considerations on Western Marxism (London: New Left Books, 1976).

3. Jánossy Ferenc, 'Egy Evolucios Alternativa' (One Evolutionary Alternative), Valóság, 1982, No.2.

4. Bélley László, 'Tulajdonviszony és Társadalmi Struktúra' (Property Relation and Social Structure), Társadalmi Szemle, 1971, No.6, p.91.

5. The most important system-typical principles of social integration based on the primacy of the political system and the power system are:

1. the communist party is the centre of the power mechanism; state bodies are only the executant of tasks;

2. the monopolistic tendency prevails in the power organization;

3. there is maximum centralization of decisions;

4. the economic and political administration is considerably swollen;

5. there is organizational concentration;

6. organizational functions interpenetrate;

7. the structure of power is based on personal dependence within the organization;

8. functions develop a 'seizure' character: everyone has as much authority at his disposal as he can seize.

On this see Bihari Mihály, Politikai Mechanizmus és Demokrácia (Political Mechanism and Democracy) (Budapest: Kossuth Könyvkiadó, 1982), pp.282-5.

6. Mátyás Rákosi, A Magyar Jövöért (For the Hungarian Future) (Budapest: Szikra Kiadás, 1947), p.373.

7. Bakcsi György, 'Forradalmak, Háborúk, Irodalom' (Revolutions, Wars, Literature), Orosz és Szovjet Irodalom 1890-töl Napjainkig (Russian and Soviet Literature from 1890 to our days) (Budapest: Gondolat Kiadó, 1976), pp.324-5. The quotation illustrates well the literature of early socialism: through the varnishing and schematism the same black and white dichotomy appears as in political thinking, since the contemporary literature did not have any (declared) function other than the service and justification of daily politics.

8. Mátyás Rákosi, 'Az Allami és Munkafegyelemröl' (On the State and Work Discipline), Report on the Meeting of the Central Committee, 30 Nov. 1951. A Szocialista Magyarországért (For Socialist Hungary) (Budapest: Szikra, 1955), p.55.

9. Ernö Gerö, 'A Magyar Népgazdaság Fejlesztésének Legközelebbi Feladatai' (Next Tasks of the Development of the Hungarian People's Economy), Report on the 
Meeting of the Central Committee of the Hungarian Socialist Workers' Party (HSWP) held on 31 May 1950, published by the Agitation and Propaganda Sectionof the Central Committee of the HSWP, (Budapest, 1950), p.11.

10. The frequent work stoppages in the United States during the Second World War constituted a most effective denial of the simplistic explanation - namely the ideological subversion of other political systems - for the various forms of worker resistance: see J.W. Kuhn, Bargaining in Grievance Settlement: The Power of Industrial Work Groups (New York: Columbia University Press, 1961), p.165.

11. Károly Fazekas, Lack of Performance and Piece-Rate System Waging in the Enterprise Economy (doctoral dissertation, Karl Marx University of Economics, Budapest, 1980). I deal with the role and effect of the Stakhanovite movement on motivation in the 1950s in my book, A Taylorizmustol a Munkásszervezeti Reformokig (From Taylorism to Work Organizational Reforms) (Budapest: Akadémiai Kiadó, in press).

12. H. Behrend, 'Financial Incentives as the Expression of a System of Beliefs', The British Journal of Sociology (1959), p.147.

13. See, for example, Lajos Hethy and Csaba Makó, A Munkásmagatartások és a Gazdasági Szervezet (Worker Behaviour and the Economic Organization) (Budapest: Akadémiai Kiadó, 1972); and H. David and C. Bernier, 'Le salaire au rendement', Institut de Recherche Appliquée sur le Travail (Montreal), 1977, No.8.

14. Staff Composition, Wage and Income Conditions of Employees in State-Owned Industry, No.9 (Budapest: Central Statistical Office, 1981), pp.29-30.

15. Tibor Huszár, Fejezetek a Munkaerkölcs Történetéböl' (Chapters from the History of Work Morale), Valóság, 1976, No.8.

16. Such cases are cited from the 1950-52 volumes of the one-time Goldberger factory newspaper Henger (Roller) by György Moldova in his report book, A Szent Tehén (The Holy Cow) (Budapest: Magvetö Kiadó, 1980), pp.164-9.

17. Az MSZMP X. Kongresszusának Jegyzökönyve (the Protocol of the Tenth Congress of the HSWP) (Budapest: Kossuth Könyvkiadó, 1971), p.94; and Az MSZMP XI, Kongresszusanak Jegyzökönyve (the Protocol of the Eleventh Congress of the HSWP) (Budapest: Kossuth Könyvkiadó, 1975), p.465.

18. Imre Pozsgai, Demokrácia és Kultúra (Democracy and Cutlure) (Budapest: Kossuth Könyvkiadó, 1980), p.74.

19. István Benke, Erdek és Ösztönzés (Interest and Incitement) (Budapest: Kossuth Könyvkiadó, 1975); Jozsef Lick, Érdek és Tevékenvség (Interest and Activity) (Budapest: Kossuth Könyvkiadó, 1979).

20. We deal in detail with the conception of interest and its objective nature in Lajos Hethy and Csaba Makó, Munkások, érdekek, Érdekegyeztetés (Workers, Interests, Interest Harmonization) (Budapest: Gondolat Kiadó, 1978), pp.107-16, 215-17.

21. In spite of the reference to the motives of human behaviour beyond interests, we should like to emphasize that this study deals with the development and role of the social capacity of interest realization - that is, it undertakes the description of one of the basic sociological components of human action. On the one hand, the individual is the subject of psychological analyses, while on the other hand, the types of individual reactions are the subject of social-psychological analyses.

22. Károly Fazekas, op. cit., pp.118-19.

23. See Robert A. Dahl, Who Governs? (New Haven, CT: Yale University Press 1961); and Robert A. Dahl, A Preface to Democratic Theory (Chicago, IL: University of Chicago Press, 1956).

24. 'Industrial relations' connotes that system of relations regulating, partly in institutionalized form, the connections between participants in a work process - state, employer, employees and their organizations - as well as the processes making possible the solution of interest and power conflicts occurring in the economy of a given social system. 